\title{
ÖLÜME BAĞLI TASARRUFLARIN YORUMU
}

\section{Nagehan KIRKBEŞOĞLU*}

\section{$\ddot{O} Z$}

Tek tarafl hukuki işlemlerden olan vasiyetnameler ve iki tarafl miras sözleşmeleri diğer hukuki işlemler gibi çoğu kez yorumlanmaya ihtiyaç gösterir. Özellikle el yazıll vasiyetnamelerin açık olmayan, yorumlanmaya muhtaç düzenlemeler içermesine slklkkla rastlanır. Ölüme bağll tasarrufların yorumunda geçerli olan irade teorisi gereğince, vasiyetname yorumlanırken mirasbırakanın gerçek iradesinin dikkate alınması ve bu iradenin araştırılarak mirasbırakanın beyanının içeriğinin tespit edilmesi gerekmektedir. Mirasbırakanın iradesini belirlemek için yorum yapılırken ise ölüme bağgl tasarrufta yer alan düzenlemelerin kelime anlamlarl ile bağll kalınmaması ve ölüme bağlı tasarruf dışı koşulların da yorumda dikkate alınması gerekir. Yorumda dikkate alınmast gereken kurallar ve yoruma ilişkin teorilerin ele alındı̆̆ bu çalı̧̧mada özellikle de vasiyetnamenin yorumunda dikkate alınması gereken hususlar incelenmiştir.

Anahtar Kelimeler: Ölüme bağlı tasarruf, yorum, açıklık teorisi, ima teorisi, miras sözleşmesi

\section{INTERPRETATION OF TESTAMENTORY DISPOSITIONS}

\section{ABSTRACT}

Testaments which are one-sided legal transactions, like other legal procedures, often need to be interpreted. It is often observed that handwritten wills contain explicit, needy interpretations. According to the will theory which is valid in the interpretation of the will, the real will of the inheritance shall be taken into consideration while interpreting the will and the content of the declaration of the inheritance shall be determined. When interpreting to determine the will of the inheritance, the regulations in the testament should not be attached to the meanings of the words and the nontestamentary conditions should be taken into consideration in the interpretation. In this study, the issues which deals with the rules and interpretation theories to be considered in the interpretation, shall be taken into account in the interpretation of the will are examined.

Key Words: Testament, Interpretation, clearance theory, implication theory, inheritance agreement

Dr., Muğla S1tkı Koçma Ünv. Fethiye İşletme Fakültesie-posta: nagehank@mu.edu.tr

ORCID: 0000-0001-8243-3034

DOI: $10.34246 /$ ahbvuhfd.637920

Yayın Kuruluna Ulaştığı Tarih : 10/07/2019

Yayınlanmasının Uygun Görüldüğ̈̈ Tarih: 12/09/2019 


\section{GíRiş}

Ölüme bağlı tasarruflarda yorum özel bir anlam taşır. Bunun nedenleri bellidir. Ölüme bağlı tasarruflar, mirasbırakanın ölümünden sonra hüküm ve sonuç doğurduklarından, yoruma muhtaç olan beyanın sahibine başvurmak imkânsız olacaktır. Dahası, el yazılı vasiyetname mirasbırakanın tek başına ve herkesten bağımsız bir şekilde kaleme alındığı için böyle bir vasiyetnamede ister istemez yoruma muhtaç ifadeler yer alabilir. Ayrıca ölüme bağlı tasarrufun düzenlendiği tarihle onun yürürlüğe girdiği tarih arasında uzun zaman geçmiş olabileceği için de bu süre içinde maddi manevi koşullar ile kişisel ilişkiler baştan aşağ 1 değişmiş olabilir.

Ölüme bağlı tasarrufun yorumu mirasbırakanın açık olmayan iradesinin ne anlama geldiğini bulmaktır. Yasanın yorumlanmasında TMK.m.1 kuralı 1şı̆̆ında izlenen yöntem bellidir. Bu yöntem çoktan alışılmış olan "öznel tarihsel yöntem” olmayıp çağdaş “nesnel güncel yöntem" dir ${ }^{1}$. Yasanın makul ve dürüst bir kişi tarafından bugün nasıl anlaşılması gerektiğini esas alır. $\mathrm{Bu}$ yorumda anayasal değer yargıları ve kamusal amaçlar da ön planda dikkate alınır.

Ölüme bağl1 tasarrufların yorumu meselesine modern kanunlar da önem vermişlerdir. Özellikle Fransız ve Alman Medeni Kanunlarında bu konu düzenlenmiştir ${ }^{2}$. Alman Medeni Kanununda ölüme bağlı tasarrufların yorumu hakkında birçok hüküm vardır. Bu hükümler, tereddüt halinde hangi esasın uygulanacağını göstermekte, hukukçuyu aydınlatmaktadır. İsviçre-Türk Medeni Kanunlarında ise yoruma ait pek az hüküm vardır. Hukukumuzda yorum hakkında dayanılabilecek genel kural TBK.m.18'dedir. Bu maddeye göre, irade beyanında bulunanın neyi kastettiğini, gerçek iradesini ve maksadını araştırmak gerekir. TBK.m.18 dışında yoruma ilişkin bazı hükümler, Medeni Kanunun miras hukuku kitabında dağınık bir şekilde bulunmaktadır. Bunlar TMK.m.504, f.2, 515, f.3, 519 f.2,3, 577 f.2, 583 f.2'dedirler. TMK.m.560 f.2 ve TMK.m.647 f.3 birer yorum kuralını kapsamaktadılar. Örneğin TMK.m.504/f.2'ye göre ölüme bağlı tasarrufta kişinin veya şeyin belirtilmesinde açık yanılma halinde mirasbırakanın arzusu kesin olarak tespit edilebiliyorsa tasarruf bu arzuya göre düzeltilir. Hemen belirtmek gerekir ki, mirasbırakanın arzusunu tespit etmek için bir yorum faaliyetine ihtiyaç vardır. $\mathrm{Bu}$ yorum faaliyeti çerçevesinde örneğin ölüme bağlı tasarrufta tasarruf dış1

$1 \quad$ LORITZ, BGB § 2084, Rn.34

2 Bkz: Fransiz MK. m. 1157 ve Alman MK.m.133, 157, 2066-2076, 2084.

198 Ankara Hacı Bayram Veli Üniversitesi Hukuk Fakültesi Dergisi C. XXIII, Y. 2019, Sa. 4 
olgulardan da faydalanılacağı için yorum faaliyetine esas kuralları iyi bilmek icap eder. Yine örneğin TMK.m.515/f.3'e göre anlamsız veya başkalarını rahatsız edici nitelikte olan koşullar ve yüklemeler yok sayılır. Bir koşul veya yüklemenin anlamsız veya başkalarını rahatsız edici niteliğini tespit etmek için her şeyden önce yine yorum faaliyetine ihtiyaç duyulur.

Biz de söz konusu çalışmada ölüme bağlı tasarrufların yorum kurallarını yakından incelemekteyiz.

\section{GENEL OLARAK}

Ölüme bağlı tasarrufun yorumu, mirasbırakanın açık olmayan iradesinin ne anlama geldiğini bulmaktır. Buna açılklayıcı yorum (erläuternde Auslegung), denir ${ }^{3}$. Genel olarak irade beyanının yorumlanmasında yerine göre ya TMK.m.2 kuralı 1şığında "güven ilkesi"nin ya da TBK.m.18 kuralı doğrultusunda irade ilkesinin yürürlüğü söz konusu olur. Güven ilkesi beyan muhatabının, içinde bulunduğu tüm hal ve koşullar dikkate alınarak dürüstlük kuralı gereğince beyana vermekte haklı olduğu anlamı esas alırken, irade ilkesi doğrudan beyan sahibinin iradesini esas alır . Açıklayıcı yorumda gerek güven ilkesinin gerek irade ilkesinin yoruma esas faaliyette esas olmas1 beklenen bir durumdur. Ölüme bağl1 tasarrufun niteliğine göre değişecek olan tercih açıklayıcı yorumun ihtiyaç duyduğu kuralı ortaya koymaktadır. Buna göre ölüme bağlı tasarruf eğer vasiyetname niteliğinde ise irade teorisi miras sözleşmesi şeklindeyse güven ilkesi prensipleri esas alınarak yorum faaliyetinde bulunulur.

Mirasbırakanın ölüme bağlı tasarrufta açığa vurduğu iradesinin tam olarak anlaşılmasına hizmet eden bu açıklayıcı yorum yanında, bir de tamamlayıcı yorum söz konusu olabilir ${ }^{5}$. Tamamlayıcı yorum (ergänzende Auslegung) ise temelde, vasiyetnamedeki boşlukların, mirasbırakanın farazi iradesine uygun olarak tamamlanmasıdır ${ }^{6}$. Tamamlayıcı yorumla

\footnotetext{
Açıklayıcı yorum mirasbırakanın ölüme bağlı tasarrufta beyan ettiği son arzularının ortaya çıkarılmaya çalışılması; mirasbırakanın beyanıyla gerçekte ne söylemek istediğinin tespit edilmesidir. ERGÜNE, s. 44; bkz. AKSOY DURSUN, s. 312; örneğin mirasbırakanın ölüme bağlı tasarruftaki "araç" sözcüğü ile otomobilini mi, motosikletini mi yoksa deniz taşıtını mı yoksa tarım makinesini mi kastettiği gibi, SEROZAN/ENGIN, § 4, s.304.; EREN/YÜCER AKTÜRK; s. 316.

4 SEROZAN/ENGIN, § 4, s. 304.

5 DURAL/ÖZ; s. 218.

6 ERGÜNE, s. 51; DIRK, s. 195, Rn.559.
} 
açıklayıcı yorum arasındaki temel fark, açıklayıcı yorumda, mirasbırakanın beyanlarıla ne söylemek istediğinin yani gerçek iradesinin araştırılması, tamamlayıcı yorumda ise mirasbırakanın farazi iradesine ulaşılarak ölüme bağlı tasarruftaki boşluk tamamlanmaya çalışılır ${ }^{7}$ Bu yorum türünü esas alan görüşe göre, mirasbırakanın esasında ölüme bağlı tasarrufa yansımamış olan iradesini araştırıp bularak, ölüme bağlı tasarrufu onun gerçek iradesine uygun olarak yerine getirmek gerekmektedir. Örneğin, mirasbırakan vasiyetnamesini düzenlerken o anda var olan durumlar esas alınır. Ne var ki, tasarrufu yaparken göz önünde bulundurduğu durumlar, vasiyetname açıldığı zaman, olağanüstü değişikliklere uğramış ve bu sebeple de mirasbırakanın vasiyetnamesini yaparken izlediği amacın gerçekleşmesi imkansız hale gelmiş olabilir. Örneğin, hısım olarak büyükbabasının babasından başka hiç kimsesi olmayan mirasbırakan eski TMK.m.444'nin yürürlükten kaldırılmasından önce örneğin 1985 tarihinde, "büyükbabamın babasinın intifa hakkı saklı kalmak kaydıyla Kızllay'ı terekemin tamamı için mirasçı atıyorum” demiş ve 2003 y1lında ölmüş olsa ne olacaktır? Çünkü mirasbırakan bu vasiyetnameyi yaparken büyük ana ve büyük babaların ana ve babaları yasal mirasçı idi ve bu sebeple de yapılan tasarrufun bir anlamı vardı. Oysa ölüm anında bu kişiler yeni Medeni Kanuna göre mirasçı değildirler. Bu durumda zaman içinde değişiklik vasiyetnameyi nasıl etkileyecektir? Aynı şekilde, mirasbırakan kızını mirasından uzaklaştırmış, fakat mirastan hiçbir şey almamasına gönlü razı olmadığ 1 için onun lehine yüklüce bir vasiyet öngörmüş ve ölümünden sonra kızı mirasçılıktan çıkarmayı iptal ettirmişse ne olacaktır? Çünkü mirasbırakan mirasçılıktan çıkarmanın geçerli olacağından hareket ederek vasiyeti yapmıştır. Onun bu düşüncesi ölümden sonra gerçekleşmemesine rağmen kızı miras payı ya da saklı payı ile birlikte vasiyeti de alacaklı sıfatıyla isteyebilecek midir? Böyle bir durum, mirasbırakanın vasiyeti yapmasındaki amaca uygun düşer mi? $\mathrm{Bu}$ ve buna benzer durumlarda nasıl hareket edileceğine ilişkin görüşler birbirinden farklıdır. Alman Hukukuna hakim olan, fakat İsviçre Hukukunda azınlıkta kalan görüş, bu hallerde mirasbırakanın farazi iradesini araştırıp ölüme bağlı tasarrufun buna uygun olarak tamamlanmasıdır ${ }^{8}$. Buna göre araştırılacak şey şudur: mirasbırakan eğer gerek maddi gerek kişisel ilişkilerde sonradan meydana gelebilecek değişiklikleri tahmin edebilseydi ne gibi bir düzenlemede bulunur, nasıl bir tedbir alırdı? İşte bu tespit edilirse, ölüme bağlı tasarruf ona göre tamamlanır.

LORITZ, BGB § 2084, Rn.34. WEIDLICH, BGB § 2084, Rn. 8.

8 Alman Hukuku için bkz: KOCAYUSUFPAŞAOĞLU. s. 326, dn.15'de anılan yazarlar. İsviçre Hukukunda bu görüşe taraftar olan yazarlar için bkz: DRUEY, § 12 N.12 vd. ; SEROZAN, s. $425 \mathrm{vd}$ 
Bu görüşü bazı açılardan sakıncalı bulmaktayız. Önce bu yol açılacak olursa, mirasbırakanın lehine tasarrufta bulunmayı hiç düşünmediği bir kimse lehine bile sonuç elde etmek mümkün olacaktır. Bu sonucun ortaya çıkması hangi yorum yolu tercih edilirse edilsin mümkün gözükmemektedir. Çünkü yorumda amaç ölüme bağlı tasarrufun içeriğini oluşturan maddi anlamda ölüme bağlı tasarruftan ne anlaşılması ve nasıl uygulanması gerektiğinin tespitidir. Vasiyetnamede yer almayan bir maddi anlamda ölüme bağl1 tasarrufun yorum yoluyla tasarrufa dahil edilmesi mümkün değildir. Nitekim mirasbirakanın iradesine uygun yorum yapmak yerine, tam aksine onun hiç istemediği bir ölüme bağlı tasarrufu yapmış saymak yolu açılmış olur. Örneğin, mirasbırakanın Darüşşafaka yazacak yerde Darülaceze yazdığı ve bunu dalgınlıktan kaynaklandığ 1 , onun gerçek iradesinin Darüşşafaka olduğu nasıl ileri sürülüp ispat edilebilir?

Bunun yanında birçok halde mirasbırakanın farazi iradesini tespit etmek mümkün olmaz, hatta tam iradenin aksi yönde tespit edilmesi mümkündür. Mirasbırakanın, büyükbabasının babasının intifa hakkını saklı tuttuğu örnekte eğer onun ileride yasal mirasçı olmayacağını bilseydi nasıl bir düzenleme getirirdi sorusuna iki farklı cevap verilebilir. Denilebilir ki, mirasbırakan onun yasal mirasçı olmayacağını bilseydi, intifa hakkını saklı tutmazdı. Ya da tam aksine ona muhakkak intifa hakkı vermek istediği için mirasçı olamayacağını bilseydi bile yine de bu hakkı tanırdı. Birinci yorum söz konusu kişinin aleyhine, ikincisi ise lehinedir ve hiç kimse bunlardan birinin mirasbırakanın farazi iradesi olmayacağını iddia edemez. Aynı durum mirasçılıktan çıkarma örneği için de söz konusudur. Acaba mirasbırakanın farazi iradesi mirasçılıktan çıkarmanın iptal edileceğini bilseydi yine kızı lehine tasarrufta bulunacağı yönünde mi olurdu yoksa tasarruf yapmaz mıydı? Eğer ikinci sonuca varılacak olursa, o zaman da bunun af sayılıp sayılamayacağına ilişkin mirasbırakanın farazi iradesi aranır; eğer af olarak yorumlanırsa o zaman da, mirasbırakanın farazi iradesinin taksim kuralı mı koymak yoksa ön vasiyet mi yapmak olduğu araştırılır.

Kuşkusuz bu görüş, ileride etraflıca açıklanacak olan favor testamenti kuralının genişleterek uygulanmasını ifade eder. Ne var ki, favor testamenti kuralını bu kadar genişleterek uygulamak, kuralın amacını aşan sonuçlara varılmasına yol açar. Kaldı ki, birçok halde sorunun, farazi iradeye başvuracak yerde, TMK.m.504 aracılığıyla açı hataya dayanılarak ya da karineler yoluyla çözülmesi mümkündür.

Yukarıdaki açıklamalardan, tamamlayıcı yorumun hiç kabul edilemeyeceği sonucunun çıkartılmaması gerekir. İtiraz, sınırsız bir şekilde 
açığa vurulmamış olan farazi iradeye göre ölüme bağlı tasarrufu yorumlayıp, mirasbırakanın dahi istemediği sonuçlara farazi olarak varılmasıdır, yoksa tümüyle red değildir ${ }^{9}$. Çünkü ölüme bağlı tasarrufun mirasbırakanın öngöremeyeceği şekilde değişmesi mirasbırakanın iradesine aykırı bir davranış olabilir. Bu bakımdan tamamlayıcı yorumu, sınırlı, belirli şartlara bağlı olarak kabul eden yazarların görüşüne katılmak yerinde olur ${ }^{10}$. Buna göre ancak ölüme bağlı tasarrufta, değişen durumlara nasıl uydurulabileceğine ilişkin tutamak noktası bulunabilirse, yani mirasbırakanın iradesinin ne yönde olabileceği saptanabiliyorsa, tamamlayıc1 yoruma gidilmelidir. Bunun ise, son tahlilde bizi açıklayıcı yoruma götüreceğini de belirtmek gerekir ${ }^{11}$.

\section{VASIYYETNAMEDE YORUM KURALLARI}

Vasiyetnamelerin yorumunda "güven ilkesine" göre yorumdan çok TBK.m.18/f.1'de ifade edilen vasiyetçinin "iç iradesine göre yorum" ilkesi ağır basar. Miras sözleşmelerinde ise "güven ilkesi"ne göre yorum tekrar önem kazanır ${ }^{12}$. Şekli anlamda ölüme bağlı tasarruf türlerinden birisi olan vasiyetnamelerde de, yorum yoluyla vasiyetnamede yer alan irade beyanlarının ne anlama geldiği araştırılarak tespit edilir ${ }^{13}$.

\section{A- ÖLÜME BAĞLI TASARRUFUN BEYAN EDİLMIŞ OLDUĞU GİBI ANLAŞILMASI}

Vasiyetnamelerin yorumunda uygulanacak kural irade prensibidir ${ }^{14}$. Bu çerçevede, yorum konusunda esas olan, vasiyetnamenin veya ölüme bağl1 tasarrufun metni ve sözüdür. Vasiyetçinin son arzu ve emirleri ancak buradan anlaşılabilir. Vasiyetnameler, tek taraflı, varması gerekli olmayan irade beyanı

9 Tümüyle tamamlayıcı yorumu reddedenlere örnek olarak; ESCHER., Vorbem 1 vd., PIOTET (1988), s. 268 vd. OĞUZMAN, s. 171; İMRE, Zahit/ERMAN, Hasan, s. 106 vd. BGE 49 II 12; 94 II 98.

10 Bkz: DRUEY, § 12 N.16'da anılan yazarlar. Ancak Druey'in kendisi bu yorum kuralını mutlak ve sınırsız uygulama taraftarıdır. ( $\$ 13$ N.12). Aynı şekilde Serozan da mutlak sınırsız uygulama taraftarıdır. (Yorum, s. 425 vd.). Bunun dışında bkz: KOCAYUSUFPAŞAOĞLU, s. 327. BGE 75 II 286, 76 II 14.

11 Federal Mahkemenin bu yöndeki uygulamaları için bkz: BGE 56 II 254; 89 II 437; 100 II 98.

12 HATEMİ, 2014, s. 121.

13 DEMIR, s. 1154; LEIPOLD, BGB §2084, Rn.3

14 AKSOY DURSUN, s. 319; DURAL/ÖZ; s. 219-220; ÖZTAN, s. 216; İNAN/ERTAŞ/ ALBAŞ; 2012, s. 267; ANTALYA/SAĞLAM, s. 233; KILIÇOĞLU, s. 190. HRUBESCHMILLAUER, s. 33. PALANDT/WEIDLICH, BGB §2084, Rn.1., EREN/YÜCERAKTÜRK; s. 317. 
ile yapılan ölüme bağlı tasarruflar oldukları için korunması gereken bir beyan muhatab1 yoktur. $\mathrm{Bu}$ sebeple yorumla bulunması gereken vasiyetçinin açık olmayan iradesinin ne anlama geldiğidir, yoksa muhatap olmadığ 1 için onun açısından beyanın ne anlama geldiği araştırılmaz ${ }^{15}$. Daha açık bir ifadeyle, Türk miras hukukunda, vasiyetin yorumlanmasında, borçlar hukukundan farklı olarak, irade nazariyesi geniş ölçüde hâkimdir. Yani, yorumda bulunurken doğrudan vasiyetçinin açı olmayan ifadeleriyle ne kastettiğinin araştırılması gerekir, yoksa herhangi bir muhatabın beyanı nasıl anlaması gerektiği dikkate alınmaz. Mirasbırakanın beyanı, bu beyana dürüstlük kuralı (TMK m.2) çerçevesinde karşı tarafın vermesi gereken anlam değil, doğrudan doğruya söz konusu beyanın arkasında yer alan ve bu beyanla ifade edilmek istenen gerçek irade araştırılarak yorumlanır. Bu irade araştırılırken ölüme bağlı tasarrufun metni ve sözü dikkate alınır ${ }^{16}$.

Ölüme bağlı tasarrufun hüküm doğurduğu an ile mirasbırakanın son arzularını beyan ettiği an arasında uzunca bir zaman geçmiş olabilir. Mirasbırakan, iradesini beyan ederken seçtiği sözcüklerde yeterince titiz davranmamış olabilir. Bunlar, onun iradesinin yorumlanmasını zorlaştıran birer etken olarak karşımıza çıkabilir. Yorumlanacak irade, yani mirasbırakanın temel alınacak iradesi, ölüme bağlı tasarrufun düzenlendiği andaki açık veya varsayılan iradesi olmalıdır ${ }^{17}$. Yorum yapılırken vasiyetname dişı olgulara başvurulması ise, ancak vasiyetnamede kendisine bir dayanak bulan irade beyanları muğlak ise, gerçek anlamını tam olarak tespit etmek amacıyla mümkün olabilir ${ }^{18}$. Aksi halde, vasiyetnamede var olmayan bir beyanı sırf vasiyetname dışı olgulara bakarak vasiyetname içeriğine sokmak mümkün olmaz $^{19}$. Ölüme bağlı tasarruf dışı olgulara bakarak tasarrufun içeriğini tespit etmek hususunda son derece titiz ve çekingen davranılmalıdır.

Vasiyetnamenin yorumunda irade beyanının hiç rolü olmadığı söylenemez. Çünkü yoruma, vasiyetçinin bir vasiyetnamede açılanmış bir iradesinin bulunması halinde başvurulur. Daha açı bir ifadeyle, yorum için,

\footnotetext{
15 PICENONI, s. 92; ESCHER, 14. Titel Einleitung N.14; PIOTET (1978), s. 207; KOCAYUSUFPAŞAOĞLU, s. 321; OĞUZMAN, s. 171.

16 PICENONI, s. 47.

17 SEROZAN/ENGIN, §4 N. 218, s. 310. ERGÜNE, s.72.

18 BGE 124 III 76. GLAUS, Hannes, Irrtumsanfechtung und Auslegung beim Testament, Zurich 1982, s.19.

19 KAHRAMAN, s. 954.
} 
vasiyetçinin şekle uygun bir irade açıklamasının varlı̆g 1 şarttır ${ }^{20}$. Bir irade beyanı yoksa ya da yapılmış olan beyan şekle uygun değilse yorum yoluyla bunları vasiyetnameye dahil edemeyiz ${ }^{21}$. Ancak yorum için şekle uygun irade beyanının varlığı şartından, mirasbırakanın her irade beyanının yorumlanacağ 1 sonucu çıkartılmamalıdır. Yorumun amacı, gerçek iradeyi tespit etmek olduğuna göre, anlamı açık ve vasiyetçinin iradesine uygun beyanlara yorum yoluyla farklı anlamlar verilemez ${ }^{22}$. Bu bakımdan vasiyetçinin sadece muğlak, eksik ya da gizli beyanları yoruma tabi olur. Vasiyetçinin açık ve net olmayan ifadeleri için başvurulacak yöntem onun gerçek iradesini tespit etmeye yönelik olan irade teorisidir. Dolayısıyla, mirasbırakanın beyanlarının yorumunda sadece onun kişisel anlayışı ölçü alınacaktır ${ }^{23}$. Mirasbırakanın kişisel anlayışının tespitinde vasiyetname dışı olguların araştırılmasının önemi büyüktür ${ }^{24}$. Ancak dikkat edilmelidir ki, sırf vasiyetnameyi ayakta tutmak uğruna vasiyetnamenin metni dikkate alınarak ulaşılamayacak bir yoruma yer verilmemelidir. Vasiyetname dışı unsurlar ancak vasiyetnamede o hususla ilgili veri olduğu taktirde dikkate alınmalıdır ${ }^{25}$.

Yoruma başvurabilmek için, vasiyetçinin iradesinin vasiyetnamede somutlaşması şartsa da, bunun yorumlanması için başvurulacak olayların da vasiyetnameden anlaşılması zorunlu değildir. Yorum için vasiyetname dışı olgulara da başvurulabilir. Örneğin vasiyetçinin mektupları, ilişkileri, öğrenimi, alışkanlıkları ya da tanık beyanları yoruma esas alınabilir. Burada esas olan vasiyetçinin vasiyetnamede kullanıldığı terimlerden çok daha önce de ifade edildiği üzere gerçek iradesi esas alınır. Bu iradenin somutlaştığ vasiyetnameden her zaman gerçek irade anlaşllamayabilir. Bu hususta vasiyetçinin muğlak ve net olmayan ifadelerinin de yoruma tabi olduğu unutulmamalidır ${ }^{26}$.

Şimdi, yukarıda izah edilenleri örneklerle açıklayacak olursak; vasiyetçinin Ahmet ve Mehmet adlı iki yeğeni olsa ve vasiyetnamesinde

\footnotetext{
20 Genel olarak kabul edilen bu fikre, mutlak tamamlayıcı yorum taraftarları karşı çıkarlar. Örnek olarak bkz: DRUEY, § 12 N.12; SEROZAN, s. 425.

21 BGE 69 II 46; 83 II 345; FAHRLÄNDER, s. 32; KOCAYUSUFPAŞAOĞLU, s. 323.

22 BGE 83 II 345.

23 LÖHNING, Rn.169; LITZENBURGER, BGB § 2084, Rn.10.

24 BGE 134 II 196

25 BGE 124 III 414.

26 PICENONI, s. 96.
} 
"Yeğenim Ahmet'i bütün terekem için mirasçı atıyorum" demiş olsa, Mehmet vasiyetçinin kendisini terekenin tümü için mirasçı atamak istediğini ileri sürerse bu iddia dinlenmez. Çünkü vasiyetnamesinde bunu gösterecek bir dayanak yoktur. Buna karşılık, vasiyetçinin Ahmet adlı iki yeğeni olsa ve vasiyetnamesinde "Yeğenim Ahmet'i terekemin tamamı için mirasçı atıyorum" demiş olsa, vasiyetçinin hangi Ahmet'i kastettiğine ilişkin yorum yapılır. Çünkü ortada, vasiyetçinin şekle uygun fakat açık olmayan bir iradesi mevcuttur. Onun gerçek iradesini bulmak için artık, vasiyetname dışı olgulara (örneğin biri ile ilişkilerinin iyi olmadığı veya birinden büyük bir iyilik gördüğü gibi) başvurulabilir. Ya da örneğin vasiyetçi arabasını kızlarında birine tahsis etmiş olsa ve vasiyetnamesinde "arabamı kızıma bırakıyorum" şeklinde bir ifade kullanmış olsa vasiyetçinin kızlarından hangisini kastettiğini anlamak için vasiyetname dışı olgulara müracaat etmek gerekecektir.

Aynı şekilde vasiyetçi vasiyetnamesinde "mirasımın yarısını oğluma bırakmak istiyorum"demiş olsa ve vasiyetçinin birden fazla oğlu olsa mirasbırakanın hangi oğlunu kastettiğini anlamak için vasiyetname dış1 olgulara müracaat etmek gerekecektir. Biraz önce de ifade ettiğimiz gibi, yorumun amacı gerçek iradenin bulunmasıdır ${ }^{27}$. Bunun hareket noktası ve aynı zamanda sınırı beyanın yapılmış olduğu vasiyetname metnidir ${ }^{28}$. Vasiyetnamede bulunmayan veya şekline uygun olarak beyan edilmemiş bir tasarruf yorum yolu ile buraya sokulamaz. İsviçre Federal Mahkemesinin bir kararında ${ }^{29}$ açıklandığı gibi, yalnız vasiyetname açık ise, yorum faaliyetinde bulunurken bu açık ifadeye itibar edilmek gerekir, mirasbırakanın maksadının başka olduğu iddia edilse bile, açık olan vasiyetnamedeki irade beyanı gerçekleştirilmek gerekir. Ancak vasiyetnamedeki tasarrufların açık olmamaları halinde, bunların yorumu yoluna gidilebilir.

Vasiyetname konusu ölüme bağlı tasarrufun içeriğinden çeşitli anlamlar çıkıyorsa, bunlardan hangisinin mirasbırakanın gerçek iradesi olduğu yorumla anlaşılabilir. Buna karşılık, ölüme bağlı tasarruf tek bir anlam taşıyorsa, vasiyetçinin bundan başka bir maksat izlediği, arzu ve iradesinin başka olduğu iddia olunsa bile, vasiyetnamede ifade olunana değer vermek aksine bir yorum kabul olunmamak gerekir. Ancak irade sakatlığ sebeplerinden biri varsa (yanılma, aldatma, tehdit) bu sebeple tasarrufun iptali istenebilir; fakat

\footnotetext{
27 IMRE/ERMAN, s. 108'den naklen.

28 ERGÜNE, s. $60 \mathrm{vd}$.

29 BGE 101 II 31.
} 
böyle bir tasarrufta mirasbırakanın irade ve maksadının başka olduğu yorumla tespit edilmek suretiyle tasarruf değiştirilemez.

\section{B- MIIRASBIRAKANIN İRADE BEYANI: İRADE TEORISİ}

Sağlararası işlemlerle ölüme bağlı tasarrufların yorumu arasında farklar vardır. Bir sözleşmeyi yorumlarken bunun objektif anlamı araştırılır. Çünkü bu sözleşme, belirli kişiler arasında yapılmıştır ve onların bundan çıkaracakları anlama göre hüküm ifade edecektir. Halbuki, ölüme bağlı tasarrufların varlıklarının tek sebebi, bunların vasiyetçi tarafından istenmiş olmasıdır. $\mathrm{Bu}$ itibarla, ölüme bağlı tasarrufu yorumlarken, vasiyetçinin ne istediğini anlamak, onun gerçek maksadını araştırmak ve bulmak gerekecektir ${ }^{30}$. $\mathrm{Bu}$ sebeple, ölüme bağlı tasarrufların yorumunda irade teorisi hakimdir ve yapılacak yorum subjektif niteliktedir.

Bu konuda şöyle bir örnek verelim; vasiyetnamesinde yasal miras hakkına sahip kız yeğenini miras dışı bırakarak, bütün malvarlığının eşine geçmesini vasiyet eden mirasbırakan, eşiyle boşandıktan bir süre sonra yeniden evlenmiş, fakat vasiyetnamesini değiştiremeden ölmüştür. Sağ kalan eş, vasiyetnameye dayanarak bütün mirasın kendisine ait olduğunu iddia edebilir mi? Alman içtihatlarına göre, vasiyetname mirasbırakanın eski eşi ile evliliği sırasında yapılmış olduğundan bu tasarruftan faydalanacak olan eski eştir, onunla boşandıktan sonra mirasbırakanın yeni eşi eskisinin yerine geçemez. Çünkü bu konuda vasiyetnamede herhangi bir kayıt bulunmadığ 1 gibi, genel hayat deneyimleri açısından da, bunu destekleyecek bir durum yoktur. Kaldı ki, eski eşiyle boşandıktan sonra onun lehine yapılmış vasiyetnamenin kendiliğinden ortadan kalkacağına ilişkin bir kanuni düzenleme de yoktur.

Başka bir örnek verelim: vasiyetçi nişanlısı lehine ölüme bağlı tasarruf yapmıştır. Ölümünden önce nişanın bozulması halinde bu tasarruf hükümsüz olur. Buna karş1ık vasiyetçinin sonradan nişanlısı ile evlenmesi halinde, ölümü anında eş sıfatını haiz bulunan eski nişanlı lehine yapılmış olan bu tasarrufun geçerli sayılması gerekir ${ }^{31}$.

\section{C- VASIYYETNAME DIŞINDAKİ SEBEP VE DELILLLRDEN FAYDALANMA}

Vasiyetnamenin metni yoruma yeterli olmazsa, bunun yanında yardımc1 olarak, dışetki veolaylara, mesela mirasbırakanınyazılınotlarına, mektuplarına,

\footnotetext{
30 BGE 64 II 187, 69 II 382, 75 II 284.

31 İMRE/ERMAN, s. 109.
} 
hısımlık ve dostluk ilişkilerine de bakmak gerekebilir. Vasiyetname dışındaki delillerin, gerek bulunduğu taktirde göz önüne alınmasını İsviçre doktrini ve içtihatları da kabul etmiştir ${ }^{32}$. Hemen ifade edelim ki, vasiyetname dışındaki olgulara ancak vasiyetnamenin yorumuna başvurulabilir; fakat vasiyetnamede yaz1l olmayan bir hususun vasiyetnameye eklenmesine hizmet edemezler ${ }^{33}$.

$\mathrm{Bu}$ konuda İsviçre Federal Mahkemesinin bir kararında şöyle denilmektedir: "Vasiyetnamede kullanılan terimlerin anlamını, vasiyetçinin gerçek maksadının ne olduğunu, vasiyetname dışındaki delillerle araştırmaya hakim yetkilidir" ${ }^{34}$. Aynı sonuç, esasen daha önceleri Alman ve Fransız doktrinde ve mahkeme içtihatları tarafından da kabul edilmiş durumdayd ${ }^{35}$.

Benzer bir içtihat Türk Yargıtayınca da benimsenmiştir ${ }^{36}$. Meseleyi bir örnekle açıklayalım: Mirasbırakan vasiyetnamesinde "arkadaşım Ahmet'e onbin türk lirası verilmesini vasiyet ediyorum" demişse ve arkadaşları arasında Ahmet ismini taşıyan iki kişi varsa, vasiyetin hangisi lehine yapıldığııı anlayabilmek için, vasiyetname dışındaki delillere de bakılmak gerekir. Bu konudaki güncel bir Yargitay kararında bu yorum kuralı şu şekilde ifade edilmiştir: "Yine vasiyetnamenin yorumunda gözönünde bulundurulması gereken kurallardan biri de, ölüme bağlı tasarrufun geçerliliğini üstün tutan, Roma Hukukundan beri geniş uygulama alanı bulan..Testemanti (vasiyetin ayakta tutulması) ilkesidir. Buna göre, mirasbırakanın ölüme bağlı tasarrufların iptalden ziyade muhafaza etmek, vasiyetçinin arzu ve iradesine daha uygun düşer. Bu itibarla, yorumda bu gayenin daima gözönünde tutulmast, şüpheli ve müphem hallerde tasarrufun muhafazası lehine yorumun yapılmasi gerekir. Önemle vurgulamak gerekir ki, normal olarak yorum, vasiyetçinin beyanında yazılı arzusunu bir dereceye kadar süzmektir. Diğer bir anlatımla, beyanda hiç bir dayană̆ yok iken onu tamamlamak değildir. Vasiyetnamenin metni yoruma kafi gelmezse, bunun yanında yardımcı olarak dış etken ve olgulara, örneğin vasiyetçinin notlarına, mektuplarına, dostlarına ve yakınlarına yaptı̆̆ açılamalara dair belgelere bakmak icap eder. İhtiyaç olduğu takdirde, tasarrufun dışındaki olgulardan, belgelerden

\footnotetext{
32 PICENONI, s. 46; FAHRLAENDER, s. 44; ESCHER; Art. 511, N.4; TUOR; Art. 511, N. 23. BGE 88 II 67, 86 II 423, 70 II 113, 64 II 187.

33 BGE 104 II 337, 103 II 88, 100 II 466; 93 II 163.

34 BGE 55 I 169; 86 II 423; 88 II 67.

35 PICENONI, s. 54.

36 Y.HGK. 7.12.1966, 2/738-309. ABD. 1967,Say1: 1, s. 97 vd.
} 
ve dayanaklardan yararlanılması gereği hukuk öğretisinde tam bir görüş̧ beraberliği içerisinde savunulmaktadır (HGK. nun 07.12.1966 gün ve 1966/2-738 E. 1966/309 K. ile 21.11.1990 gün ve 1990/2-346 E. 1990/586 K. sayılı ilamlarl da aynı yöndedir) ${ }^{\prime 37}$.

Belirtmek gerekir ki; vasiyetnamenin yorumunda yardımcı olarak etkili olabilecek dış sebep ve deliller, yalnız şekil kurallarının ön planda tutulduğu delillerdir. Mirasbırakanın yazıları, not ve mektupları bu açıdan önem taşıyabilir. Buna karşılık, esas itibari ile, yorum faaliyetinde bulunurken tanık dinlenilmesi yoluna gidilmemek ve tanıkların ifadeleri bu konuda göz önüne alınmamak gerekir ${ }^{38}$.

Burada göz önünde tutulacak dış olgular arasında, yukarıda söylenilenlerden başka mirasbırakanın söz konusu kişilerden birine karşı duyduğu içten sevgi ve samimi dostluk hisleri veya nefret ve kin duyguları da vardır. Ayrıca vasiyetçinin bağlı olduğu muhite, öğrenim ve terbiye derecesine ve ifade kabiliyetine de bakmak lazımdir ${ }^{39}$.

\section{D- "FAVOR TESTAMENTI" KURALI}

Yorum konusunda çok eski ve yaygın bir ilkeye göre, mirasbırakanın irade beyanı çeşitli şekillerde anlaşılabiliyorsa, vasiyetnameyi ayakta tutan, böylece mirasbırakanın son arzularının hüküm ifade etmesini sağlayan yoruma üstünlük tanınacaktır ${ }^{40}$. Buna, "vasiyetnameyi kurtarıcı yorum ilkesi" de denilir ${ }^{41} . \mathrm{Bu}$ ilke Türk Medeni Kanununda açıkça belirtilmiş olmamakla birlikte genel bir Miras Hukuku ilkesi olarak kabul görmektedir ${ }^{42}$. Amaç, mirasbırakanın önceden yapmış olduğu tüm ölüme bağlı tasarrufları ayakta tutmak değildir. Sadece yorumlanmakta olan beyanı içeren vasiyetnamenin ayakta tutulmasını sağlayacak yorumun tercih edilmesidir. Asıl olan, mirasbırakanın son arzularını

\footnotetext{
37 Y.3.HD. T.18.5.2016, E. 2015/15137, K. 2016/7741 (Kazancı İçtihat Programı) erişim tarihi: 05.06.2019.

38 IMRE/ERMAN, s. 110-111.

39 İMRE/ERMAN, s. 111.

40 KOCAYUSUFPAŞAOĞLU, s. 323; İMRE/ERMAN, s. 113 ve 117 vd.; STEINAUER, N.294; PIOTET (1978), s. 195.

41 SEROZAN/ENGIN, §4 N. 219; HATEMİ, §10 N.4.

42 Bkz. ERGÜNE, s. 74 vd. Buna karş1lı, söz konusu ilkenin BGB §2084 hükmünde açıkça ifade edildiğini görmekteyiz. Söz konusu hükme göre; "Bir ölüme bağll tasarrufun içeriğinin farklı şekillerde yorumlanması mümkünse, tasarrufun sonuç doğurmasına imkân sağlayan yoruma öncelik tanınır."
} 
yerine getirmektir ${ }^{43}$. Bununla kastedilen, bilgisizliği, kelimelerin anlamları üzerindeki yanlış tasavvurları, dalgınlığı vb. gibi sebeplerle iradesiyle tam uyuşmayan, sınırları belli olmayan ve şüpheli beyanlarının yorum yoluyla hükümsüz sayılması yerine geçerli olmalarını sağlayacak yorum metodunun uygulanması ve bu suretle son yapmış olduğu ölüme bağlı tasarrufun hükümsüz sayılmasının önlenmesidir ${ }^{44}$. Bu aynı zamanda, mirasbırakanın son arzularına karşı gösterilen saygının bir gereğidir ${ }^{45}$. Mirasbırakanın son dileği, mümkün olduğunca yaşama geçirilmeye çalış1lacak ve bu dileğe geçerlilik kazandıracak yorum metodu tercih edilecektir. Zira mirasbırakan, ölüm gününden sonra bu tasarrufu geçerli olacak şekilde düzeltme veya yeniden yapma şansına sahip olmayacaktır ${ }^{46}$.

Favor testamenti kuralı Medeni Kanunda doğrudan düzenlenmiş değildir. Buna karşılık BGB § 2084 bu kuralı "Bir ölüme bağlı tasarrufun içeriğini farklı şekillerde yorumlanması mümkünse, tasarrufun sonuç doğurmasina imkan veren yoruma öncelik tanınır" şeklinde belirtmiştir. Bu hükümden hareket edince, favor testamentinin, yapılmış olan ölüme bağlı tasarrufun mümkün olduğu kadar geçerliliğini temin etmeye yönelik bir yorum kuralı olduğu kendiliğinden anlaşılır. Çünkü, bu kural sayesinde bir ölüme bağlı tasarrufun ya da bir hükmünün hem geçerli hem de geçersiz sayılacak şekilde yorumlanması mümkünse, onu geçerli yapacak yoruma üstünlük tanınır ve böylece mirasbırakanın son arzularına mümkün olduğu kadar saygı gösterilmiş olur ${ }^{47}$. Zaten Roma Hukukundan beri gelen bu yorum kuralının amacı da budur.

Bu konudaki güncel bir Yargıtay kararında bu yorum kuralı şu şekilde ifade edilmiştir. "Kural olarak, murisin ölüme bağll tasarruflarını iptal etmekten veya hükümsüz saymaktan çok, bunları muhafaza etmek, vasiyetçinin iradesine ve isteğine daha uygun düşer.Roma Hukukundan gelen ...yani vasiyetnamenin muteber tutulması kuralı, Türk Medeni Kanununda açıkça belirtilmemekle beraber, gerek doktrinde ve gerek mahkeme içtihatlarında ölüme bağlı tasarrufların yorumlanmasında uygulanacak temel kurallardan

\footnotetext{
43 ŞENER, Esat, Vasiyet Hukuku, Turhan Kitabevi, Ankara 1995, s. 103, ERGÜNE, s. 77.

44 Bkz. BGE 50 II 441, 446; BGE 83 II 427, 435 vd. (www.bger.ch).

45 KOCAYUSUFPAŞAOĞLU, s. 323; ESCHER, N.13; İMRE/ERMAN, s.117. Ayrıca bkz. BGE 49 II 12, 18; BGE 94 II 88, 93 (www.bger.ch).

46 SEROZAN/ENGIN, §4 N. 219.

47 ŞENER, s. 346'da anılan kararlar ve Y. HGK. T. 21.11.1990, 2-346/586 (YKD 1991, c. XVII, 661).
} 
biri olarak kabul edilmektedir:Bu yorum tarzl, ölüme bağl tasarrufu imkan olduğu ölçüde geçerli saymaya, onu ayakta tutmaya başka bir ifade ile tasarruf yapanin gerçek iradesini, son arzularını, isteklerini elden geldiği kadar değerlendirmeye, onu üstün tutmaya, ona saygl ve bağlllık göstermeye yönelmiş bulunmaktadır.Türk Medeni Kanunu'nunda favor testamenti kuralını düzenleyen genel mahiyette bir hüküm bulunmamakla birlikte bazı maddelerde (örn. Eski MK.'nun 451/2;462/2-2;466/2 maddeleri) (yeniTMK'nu 504/2; 515/2; 519/2 maddeleri) bu kuralın uygulanmasina yer verilmiştir.Kural olarak vasiyetnamenin yorumunda murisin iradesini ayakta tutacak bir yol izlenmeli ve azami biçimde murisin iradesi yerine getirilmeli, vasiyetnamenin tenfizine imkan sağlanmalıdır (YHGK, 07.06.1966 tarih, 738/309)" ${ }^{48}$.

Hemen belirtmek gerekir ki; bu yorum, yukarıda sık sık değinildiği gibi, ancak bir ölüme bağlı tasarrufta, eksik olsa bile, bir irade beyanının bulunduğu hallerde yapılabilir. Çünkü favor testamentinin amacı, şekil kurallarına uygun yapılmamış olan bir beyanı vasiyetnameye dahil etmek değil; şekle uygun yapılmış, eksik ya da açık olmayan bir irade beyanına açıklık getirmek ve mirasbırakanın gerçek maksadını ortaya çıkarmaktır ${ }^{49}$. Buna karşılık, yorum yapılırken, vasiyetname içi olgular yanında, vasiyetname dışı olgulara da başvurulabileceğini bir defa daha hatırlatalım.

Medeni Kanunun BGB'den farklı olarak favor testamentiye yönelik bir genel kural içermediğinden yukarıda söz edilmişti. Ancak yazarların çoğunluğu, münferit bazı hükümlerde bu kuralın öngörülmüş olduğu görüşündedirler ${ }^{50}$. Örneğin, TMK.m.504/f.2'ye göre; “Ölüme bağll tasarrufta kişinin ve şeyin belirtilmesinde açı yanılma halinde mirasbırakanın gerçek arzusu kesin olarak tespit edilebilirse, tasarruf bu arzuya göre düzeltilir". $\mathrm{Bu}$ hükme göre, vasiyetçi iradede değil de, beyanda hata yapmışsa, yani doğru olan iradesini dişa yanlış aksettirmişse ve gerçek iradesinin ne olduğu açık olarak anlaşılıyorsa, o zaman mirasçılar, TMK.m.557 b.2'ye dayanarak vasiyetnameyi iptal ettiremezler; tasarruf, vasiyetçinin gerçek iradesine göre

\footnotetext{
48 Y.3.HD. T. 17.12.2018, E. 2018/7112, K. 2018/12816. (Kazancı İçtihat Programı) erişim tarihi: 06.05.2019.

49 BGE 50 II 446; FAHRLAENDER, s. 82; PICENONI, s. 59; Y. HGK. T. 21.11.1990, 2-346/586 (YKD 1991, c. XVII, 661).

50 TUOR; Dritter Abschnitt Vorbem. 16; ESCHER; Einleitung zum 14. Titel N.16; PICENONI, s. 59; FAHRLAENDER, s. 82; DRUEY; § 12 N.22-23; PIOTET (1978), s. 211 vd. OĞUZMAN, s. 172; KOCAYUSUFPAŞAOĞLU, § 27, II, 2, a.
} 
yorumlanıp, favor testamenti kuralı gereğince vasiyetçinin istediği sonucun doğması temin edilir. Örneğin, mirasbırakan vasiyetnamesinde, "yeğenim Ahmet'e otomobilimi vasiyet ediyorum" demiş olsa ve onun bir tek Mehmet adlı yeğeni varsa, tasarruf beyan hatası sebebiyle iptal edilmeyip, gerçek iradesine uygun yorumlanıp, geçerli sayılır.

Benzer şekilde; mirasbırakan ölümünden sonra hayvanının, mesela kuş veya köpeğinin bakılabilmesi için, bunun lehine mal vasiyeti yapmıştır. Hayvanlar hak ehliyetine sahip olmadıklarından, bu tasarruf geçerli değildir. Ancak, mirasbırakanın isteğinin gerçekleşmesi için bu bağış eğer imkanı varsa, mirasçılara yüklenen bir mükellefiyet (yükleme) olarak alınabilir (TMK.m.515) ve bu şekilde yorumlanabilir.

Favor testamenti kuralının Medeni Kanunumuzdaki önemli bir diğer örneği de TMK.m.504/f.2 hükmünde görülmektedir. Buna göre, vasiyetçinin vasiyetnamesinde ifade yanlışları yapması, fakat onun gerçek maksadının hiçbir şüpheye düşülmeksizin tespit edilebilmesi durumunda, bu irade beyanı gerçeğe uygun olarak bu doğrultuda yorumlanır ve mirasbırakan tarafından yapılmış olan yanılma bir iptal sebebi teşkil etmez. Vasiyetçinin hukuki ve teknik terimleri veya lehine vasiyet yaptığı kişinin isim ve niteliklerini yanlış yazması veya vasiyetnamede bazı gösterme hataları yapması halinde, gerçek durum şüpheye yer vermeyecek şekilde tespit edilebilir olmak şartıyla bu tasarruf vasiyetçinin gerçek iradesine uygun olarak düzeltilir ${ }^{51}$.

Ölüme bağlı tasarrufun tahvil (çevirme) yoluyla ayakta tutulması da favor testamenti kuralının bir sonucudur. Bunun dayanağı olarak, "Tüzel kişiliği bulunmayan bir topluluğa belli bir amaçiçinyapılan kazandırmaları, otopluluk içindeki kişiler, mirasbirakan tarafindan belirlenen amacı gerçekleştirmek kaydiyla birlikte edinmiş olurlar; amacın bu yolla gerçekleşmesine olanak yoksa, yapılan kazandırma vakıf kurma sayılır" diyen TMK.m.557/f.2'yi göstermektedirler ${ }^{52}$.

Maddi anlamda ölüme bağlı tasarruflarda favor testamenti kuralının uygulanacağında kuşku olmamakla beraber, aynı kuralın şekil eksikliğinde de uygulanıp uygulanamayacağı tartışmalıdır ${ }^{53}$.

51 Y. HGK. T. 21.11.1990, 2-346/586 (YKD 1991, c. XVII, 661).

52 OĞUZMAN, s. 173; SEROZAN, s. 172; DURAL/ÖZ, s. 222.

53 Tartışmalar için bkz: ESCHER, Art. 467, 469, Vorbem. 21; Art. 469 Einleitung N.16; Tuor, Art. 481, Vorbem. 16; DRUEY, § 12 N.22; OĞUZMAN, s. 172; KOCAYUFUPAŞAOĞLU, $\S 27$ II 2, a. BGE 101 II 31. 


\section{E- YORUMUN YASAL MIRASÇILIK LEHINE YAPILMASI}

Vasiyetçini son arzularını yazarken, yasal mirasçılığı düşünmüş olması kuvvetle muhtemeldir. Şüphe halinde, yorumu yasal mirasçılık lehine yapmak gerekmektedir. Alman Medeni Kanununda genel bir kural olarak ifade olunan bu esas, Medeni Kanunumuzda özel bazı hükümlerde göz önüne alınmıştır. (TMK.m.560/f.2, 583/f.2, 647/f.3).

Tereddüt doğuran şüpheli hallerde, yorumun yasal mirasçılık lehine yapılması gerektiği kuralını benimsemek doğru bir yaklaşımdır. Bu her ne kadar kanunda genel olarak ifade edilmemiş bulunuyorsa da, kanunun boşluklarını doldurmaya çalışan doktrine ait bir kural olarak uygulamada önem ve değer taşıyabilir ${ }^{54}$.

Örneğin, mirasbırakan vasiyetnamesinde "yasal mirasçılarımı mirasçı atıyorum" demişse, bununla üç zümrede bulunan bütün mirasçıları mı yoksa sadece yasal miras hakkına sahip olabilecek mirasçıları $\mathrm{m}$ ifade etmek istemiştir? Böyle bir ölüme bağlı tasarruf, yasal miras hakkını kazanabilecek mirasçılar lehine yorumlanmak gerekir.

Aynı şekilde, vasiyetnamede "eşimle çocuklarımı miraş̧ı atıyorum" diye yazılı bulunuyorsa, tereke malları bunlar arasında eşit olarak mı paylaştırılacaktır yoksa bunların yasal miras hakları oranında bir paylaşma mı yapılacaktır? Vasiyetnamede bir açıklık bulunmadığına göre, bu kişiler yasal miras hakları oranında mirasçı atanmış sayılırlar.

Başka bir örnek daha verelim: Mirasbırakanın "çocuklarımı mirasçı atıyorum" veya "mallarımı çocuklarıma vasiyet ediyorum" şeklinde bir ölüme bağlı tasarruf yapması halinde, vasiyetnamenin düzenlenmesinden önce ölen bir çocuğun çocukları (mirasbırakanın torunları) da bundan faydalanabilir mi? Alman Hukukunda, böyle bir halde, torunların ölmüş babaları lehine yapılan bağışı alabilecekleri kabul edilmektedir. Çocuğun, vasiyetnamenin düzenlenmesinden sonra fakat vasiyetçiden önce ölmesi halinde, aynı hüküm öncelikle uygulanacaktır (BGB § 2068-2069) ${ }^{55}$.

Yorumun yasal mirasçılık lehine yapılmasının kökeni Roma Hukukuna kadar dayanır. Bir köleyi azat etmek isteyen muris vasiyetnamesinde kölenin lehine bazı tasarruflarda bulunurdu ${ }^{56}$. Böylelikle kölenin yasal mirasçılardan olduğu yönünde kabulden yararlanılırd.

\footnotetext{
54 IMRE/ERMAN, s.112-113'den aynen.

55 IMRE/ERMAN, s.112'den aynen

56 PICENONI, s. 13; PIOTET (1988), s. 278.
} 


\section{F- YASAL MIIRASÇI LEHINE YAPILAN KAZANDIRMANIN AKSİ ANLAŞILMADIKÇA PAYLAŞTIRMA KURALI KABUL EDILMESİ}

Bunun anlamı, mirasbırakanın bir ölüme bağlı tasarrufile yasal mirasçıları lehine yaptığı kazandırmaların, aksi anlaşılmadıkça, yasal paylaştırma kuralı olarak kabul edileceğidir. Yani, yasal paylaştırma kuralları lehine, aksi ispat edilebilen bir karine vardır. Bu kuralın öngörüldüğü iki madde TMK.m.560/f.2 ve 647/f.3'dür. TMK.m.560/f.2'ye göre; 'Yasal mirasçıların paylarına ilişkin olarak tasarrufta yer alan kurallar, mirasbırakanın arzusunun başka türlü olduğu tasarruftan anlaşılmadıkça, sadece paylaştırma kuralları sayılır”. Diğer taraftan şüphe halinde yasal mirasçılığa üstünlük verilmesi kuralı (Goldene Regel) hakimdir. Hükümde ifade edildiği üzere, mirasbırakanın yasal mirasçılarının paylarına ilişkin tasarruflarının esas olarak paylaştırma kuralı kabul edilmesi, yasal mirasçı lehine yapılan tasarrufların onların miras hisselerine mahsuben yapıldıklarının varsayılmasını, tersinden bir ifadeyle, miras hisselerine ilave edilecek bir vasiyet olarak kabul edilmemesini ifade eder. Örneğin $\mathrm{M}$, vasiyetnamesinde, Tekirdağ'da bulunan yazlığının eşi $\mathrm{E}$ ve oğlu B arasında paylaşılmasını istemiş̧ir. Şimdi, bu paylaşmanın nasıl yapılacağ 1 iki şekilde yorumlanabilir. Denilebilir ki M, Tekirdağ'da bulunan yazlığını E ile B arasında eşit olarak paylaşılmasını, yani her birinin payın $1 / 2$ 'sini almasını istemiştir ya da M, E ve B'nin bu yazlığ kendi yasal miras pay1 oranlarına uygun olarak paylaşmalarını istemiştir ${ }^{57}$. Bu durumda TMK.m.560/f.2 paylaşma kuralı lehine bir karine koymuş olduğu için, paylaşma miras payları oranında yapılır. Böylece $E$, yazlığın 1/4'ünü, B ise 3/4'ünü alır. Ancak vasiyetnamenin yorumundan M'nin iradesinin aksi (E ve B'nin eşit paylaşması) yönde olduğu anlaşılırsa, o zaman buna uygun olarak paylaşma yapılı1 ${ }^{58}$.

TMK.m.647/f.3 hükmü ise, bir ölüme bağlı tasarruf ile terekede bulunan bir malın, mirasçılardan birine tahsisi öngörülmüşse, bunun paylaşma kuralı sayılacağını öngörür, meğer ki mirasbırakanın iradesi, bunun paylaşma kuralı değil de bir vasiyet olarak yapıldığı şeklinde yorumlansın. Örneğin, M, vasiyetnamesinde otomobilini oğlu A'ya tahsis etmişse, TMK.m.647/f.3'e göre bunun anlamı, A'nın otomobili miras payına mahsup etmesidir. Ancak M'nin bunu A'ya vasiyet ettiği yorum yoluyla anlaşılırsa, A miras payından

\footnotetext{
57 DURAL/ÖZ; s. 222'den naklen

58 Örnek ve açıklama için bkz: DURAL/ÖZ; s.223'den naklen
} 
ayrı olarak otomobili de alır $r^{59}$. Vasiyetname metninden paylaşma kuralı mı yoksa vasiyet mi olduğu anlaşılamazsa eğer vasiyetname dişı olgulara müracaat edilmek gerekecektir. Vasiyetnamede kullanılan terimler ve tasarruf konusu malın nasıl kullanılmak istendiğine ilişkin tasarruf dışı olgular bu hususta yol gösterici olacaktır.

\section{G- ŞÜPHE HALINDE ÖLÜME BAĞLI TASARRUFUN MİRASÇI ATAMASI OLARAK YORUMLANMASI}

Bir ölüme bağlı tasarrufun mirasçı ataması mı yoksa vasiyet mi olarak yorumlanacağ1 meselesi TMK.m.516/f.2'de düzenlenmiştir. TMK.m.516/ f.2'ye göre, "Bir kimsenin mirasin tamamı veya belirli bir oraninı almasinı içeren her tasarruf mirasçı atanması sayılır". Bu hüküm, mirasbırakanın yaptığg tasarrufun niteliğinin ne olduğunun, onun kullandığ1 terimlere göre değil de, gerçek iradesine göre tespit edileceğini ifade etmektedir. Vasiyetnamelerde irade teorisi esas alındığından mirasbırakanın vasiyetname metninden çıkan gerçek iradesi esas alınarak yorum yapılmalıdır. Bu hususta vasiyetnamede kullanılan terimler değil, miras bırakanın gerçek iradesi esas alınır. Buna göre ölüme bağlı tasarrufta mirasın belirli bir kısmı veya tamamı bırakılıyorsa tasarruf mirasçı ataması, belirli bir mal bırakılıyorsa vasiyet olarak dikkate alınacaktır. Özellikle yapılan tasarrufun belirli bir mal bırakma vasiyeti mi yoksa mirasçı atama mı olduğunun tespitinde bu hükme başvurulur. Örneğin, mirasbırakan A’ya terekesinin 1/4’ünü vasiyet ettiğini belirtmesine rağmen bu tasarruf mirasçı ataması olarak kabul edilir. Çünkü TMK.m.516/f.2'ye göre, terekenin kesirli bir bölümünün tahsisi, mirasç1 atamadır. Bunun aksine, mirasbırakan bir halısı için A'yı mirasçı atadığını belirtmişse, bu tasarruf niteliği gereği vasiyet olarak yorumlanır ${ }^{60}$. Çünkü tasarrufun konusu terekenin kesirli bir bölümü değil, terekedeki belirli bir mal, yani halıdır. Buna karşılık, bir çiftliği ve bankada 20 bin liradan başka bir şeyi olmayan bir kimse, çiftliğini arkadaşı A'ya vasiyet ettiğini belirtirse, bu tasarruf bir mirasçı atanması olarak kabul edilir. Çünkü yapılan tasarruf hemen hemen terekenin tamamına tekabül etmektedir ki; bu da TMK.m.516/f.2'ye göre mirasçı atanmasından başka bir şey değildir. Aynı şekilde mirasbırakan mirasından belirli bir malı oğluna bıraksa bunun vasiyet olduğu anlaşılması gerekir. Vasiyetnamede kullanılan terimler ve vasiyetname dışı olguların bu

\footnotetext{
59 DURAL/ÖZ; s. 222-223'den naklen.

60 DURAL/ÖZ; s. 223.
}

214 Ankara Hacı Bayram Veli Üniversitesi Hukuk Fakültesi Dergisi C. XXIII, Y. 2019, Sa. 4 
hususta dikkate alınması gerekmez ${ }^{61}$. Zira bir mirasın belirli bir orana göre mi yoksa sadece belirli bir malın $\mathrm{m}$ tasarrufa konu edileceği meselesini mirasbırakanın tespit edilecek gerçek iradesine göre halletmek gerekecektir.

\section{VASIYYETNAMELERIN YORUMU BAKIMINDAN ILLERI SÜRÜLEN TEORILER}

\section{A- AÇIKLIK TEORISII}

Açıklık teorisi gereği, bir beyanın ancak birden fazla anlama gelmesi veya anlamının belirsiz olması durumunda yorum faaliyetine konu edilebileceği kabul edilmektedir ${ }^{62}$. Bu teoriye göre, kullanılan kelime, herhangi bir tereddüde yer vermeyecek kadar net ise yorum yapilamaz ${ }^{63}$. Yorum yapılırken, vasiyetname metni dişında yer alan durum ve koşullara da ancak vasiyetname metninde yer alan ifadelerin anlamının şüpheli olması, birden çok anlama gelmesi veya birden fazla şekilde yorumlanabilme olasılığ bulunması durumunda başvurulabilir ${ }^{64}$.

Hem Alman hem de İsviçre Hukukunda, ölüme bağlı tasarrufların yorumunda, açıklık teorisinin geçerli olmaması gerektiği öğretide genel olarak kabul görmektedir ${ }^{65}$. Nitekim çok açık gözüken ifadelerin bile aslında yorumlanmaya ihtiyacı vardır ve bir ifadenin açık nitelikte olup olmadığını tespit etmek de bir tür yorum faaliyetidir ${ }^{66}$. Ölüme bağlı bir tasarrufun " $a c ̧ ı$ " nitelikte olduğunun kabul edilebilmesi için onun sadece metnine bakmak yeterli olmayacaktır. Zira ölüme bağlı tasarruflar, ancak mirasbırakanın kişisel durumu ve düşünce dünyası dikkate alınarak "açık veya açık olmayan" nitelikte bir tasarruf olarak nitelendirilebilir. Bu bağlamda, bir ölüme bağlı tasarrufun açık olup olmadığı da ancak ölüme bağlı tasarruf dışındaki durum ve koşullar dikkate alınmak suretiyle belirlenebilir ${ }^{67}$. Türk Hukukunda da öğretide,

\footnotetext{
61 PICENONI, s. 106.

62 AKSOY DURSUN, s. 322; ÖZTAN, s. 217.

63 ESCHER, Einleitung, N.13; SEILER, N. 554.

${ }^{64}$ BGE 120 II 182, 184. Bkz. RASELLI, s. 1264.

65 İsviçre Hukuku bakımından bkz: BREITSCHMID, s. 281; DRUEY, §12, Rn.12. Alman Hukuku bakımından bkz. LÜBTOW, Ulrich; Erbrecht, 1.Halbband, Berlin, 1971 s. 265; KÖSSINGER, Rn. 21; SOERGEL/LORITZ BGB §2084, Rn.7.

66 SEROZAN/ENGIN, § 4, Nr. 223a. ÖZTAN, s. 217; AKSOY DURSUN, s. 322; MANSEL, BGB §133, Rn. 2; RASELLI, s. 1265.

${ }^{67}$ DRUEY, §12, Rn.12.
} 
açıklık teorisinin uygulanmaması gerektiği ifade edilmektedir ${ }^{68}$. İsviçre Federal Mahkemesi'nin, vasiyetnamelerin yorumu bakımından ise birçok kararında, açıklık teorisine, hatta artık kalıplaşmış cümlelerle atıf yaptığı ifade edilmelidir ${ }^{69}$. Nitekim bu kararlarda genel olarak, vasiyetnamelerin yorumunda öncelikle onun metninden hareket edilmesi gerektiği; vasiyetname metni tek başına dikkate alındığında açık bir sonuca ulaşılıyorsa, bu beyan dâhilinde kalınması gerektiği belirtilmektedir. Buna karşıllı, Federal Mahkeme'ye göre, vasiyetnamede yapılan düzenlemelerin birden fazla anlama gelebilecek nitelikte olması veya farklı şekilde yorum yapılmasının haklı gerekçelere dayanması durumunda, vasiyetname metni dışındaki ispat araçlarının yorumda dikkate alınması söz konusu olabilecektir ${ }^{70}$.

Alman Federal Mahkemesi ise vasiyetnamelerin yorumunda açıklık teorisini uygulamamaktadır. Nitekim Alman Federal Mahkemesi önceleri kabul ettiği "açık kelime anlamının yoruma sınır olduğu” anlayışın $1^{71} 1982$ yılında verdiği kararıyla ${ }^{72}$ terk etmiş ve vasiyetnamenin açık metnine rağmen yorum yapılabileceğini kabul etmiştir. Buna göre, vasiyetname metninin görünüşte açık ve kesin olması, yorum için bir sınır oluşturmayacaktır ${ }^{73}$.

\section{B- İMA TEORİSi}

İma teorisi, şekle bağlı hukuki işlemlerde ve bu arada vasiyetnamelerde, beyanda bulunanın iradesinin belgede tam olmasa da en azından ima edilmek suretiyle ifade edilmiş olması gerektiği şeklinde tanımlanmaktadır ${ }^{74}$. Türk Hukukunda da ima teorisi genel olarak, mirasbırakanın iradesinin ancak vasiyetname metninde şekil koşullarına uygun olarak ima edilmişse, bu ima (dayanak, bağlantı noktası) dikkate alınarak iradeyi açıklamaya yönelik

68 SEROZAN/ENGIN, § 4; Nr. 223; AKSOY DURSUN, s. 322; ERGÜNE, s. 35.

69 BGE 83 II 427, 435; bkz. BGE 100 II 440, 446; BGE 120 II 182, 184; BGE 115 II 323, 325; BGE 131 III 601 vd., son karar için bkz. FANKHAUSER, s. 752 vd.

70 İsviçre Federal Mahkemesi’nin, 2014 tarihli kararında (BGer 5A 914/2013, 04.04.2014, https://www. swisslex.ch, erişim tarihi: 31.01.2019) "açıklık" teorisini desteklediği yönünde, HRUBESCH-MILLAUER, /BOSSHARDT, s. 508; ayrıca bkz. SEILER, Rn.554.

${ }^{71}$ Bu yöndeki kararlar için bkz: SCHERER, s. 303.

72 BGH, NJW 1983, 672.

73 ÖNCÜ, s. 314-317'den naklen.

74 SCHERER, s. 303; PALANDT/WEIDLICH, BGB § 2084, Rn.4; ÖNCÜ; s. 317-318'den naklen. 
yorum yapılabileceği şeklinde tanımlanmaktadır ${ }^{75}$. İsviçre Hukukunda ise ima teorisinin daha ziyade yoruma sınır getiren bir kural olarak görüldüğü anlaşılmaktadır. Buna göre, açıklık teorisi, vasiyetname metninin " $a c ̧ ı k$ " olmamasından dolayı, vasiyetname dişı koşullar dikkate alınarak yorum yapılmasına izin verse bile; vasiyetname dişı durum ve koşullar, ancak, mirasbırakanın bu durum ve koşullar temelinde belirlenen iradesi vasiyetname metninde en azından ima edilmişse dikkate alınabilecektir ${ }^{76}$. Mirasbırakanın gerçek iradesinin belirlenmesi için yapılacak yorumda, vasiyetname metni belirleyici olup, dış olguların dikkate alınabilmesi için ölüme bağlı tasarrufta bu yönde bir dayanak bulunması gerekecektir ${ }^{77}$. Türk öğretisinde vasiyetnamenin yorumunda ima teorisinin uygulanması gerektiği genel olarak kabul edilmektedir ${ }^{78}$. Öğretide genel olarak, ölüme bağlı tasarruf metninde hiçbir dayanağı bulunmayan bir arzunun, yorum yolu ile ölüme bağlı tasarrufa eklenemeyeceği, zira ölüme bağlı tasarrufların tabi olduğu şekil kurallarının buna engel olacağı ifade edilmektedir ${ }^{79}$. Bununla birlikte, ima teorisinin uygulanmasına karşı çıkan görüşler de bulunmaktadır ${ }^{80}$. Yargıtay kararlarında, vasiyetnamelerin yorumunda uygulanacak olan kurallar olarak, vasiyetnamenin metnine bağlılık, mirasbırakanın iradesine bağlılık ve dış etmenlerle bağlılık olmak üzere genel olarak üç başlık belirtmektedir ${ }^{81}$. Alman

75 AKSOY DURSUN, s. 323, SEROZAN, (SEROZAN/ENGIN, §4.), Nr.223b.

76 RASELLI, s. 1262, 1264; FANKHAUSER, s. 754.

77 ERGÜNE, s. 45.

78 KOCAYUSUFPAŞAOĞLU, s. 322; OĞUZMAN, s. 171; İNAN/ERTAŞ/ALBAŞ, s. 267; ERGÜNE, s. 46; DURAL/ÖZ, s. 220, Nr. 974, 976; bir görüşe göre de: "Eğer mirasbırakanın irade açıklamasının vasiyetname içinde bir dayanağı bulunmuyorsa, vasiyetname dışında yer alan o tasarruf, şekle aykırılıktan dolayı geçersizdir.” ANTALYA/SAĞLAM, s. 235.

79 OĞUZMAN, s. 171; KOCAYUSUFPAŞAOĞLU, s. 322; vasiyetnamede bulunmayan veya şekline uygun olarak beyan edilmemiş bir tasarrufun, yorum yolu ile buraya sokulamayacağ 1 yönünde, IMRE/ERMAN, s. 114; bkz. BAYGIN, s. 572.

80 Bkz. SEROZAN, (SEROZAN/ENGIN, § 4.) s. 426, Nr.223 vd.; AKSOY DURSUN, s. 323 vd.

81 “...Vasiyetnamenin yorumunda uygulanacak olan genel kurallar ise; vasiyetnamenin metnine bağlılık, mirasbırakanın iradesine bağllık ve dış etmenlerle bağllık olmak üzere üç başlık altında toplanmaktadır. Ölüme bağlı tasarrufun yorumlanmasinda genel olarak uygulanacak ilk kural, ölüme bağll tasarrufun metnine bağll kalınmasıdır. Vasiyetnamenin metninde yer almayan bir olgu ise, vasiyetnamenin yorumu ile var kabul edilemez. Tasarrufun yorumlanmasında uygulanacak bir diğer kural ise, mirasbırakanın iradesine göre yorum yapmaktır. Kural olarak vasiyetnamenin yorumunda, murisin iradesini ayakta tutacak bir yol izlenmeli, azami biçimde murisin iradesinin açığa çıkarılmasına gayret gösterilmeli ve vasiyetnamenin tenfizine imkan sağlanmalıdır...” 3. HD, E. 2013/18683; K. 2013/18151, https://emsal.yargitay.gov.tr (erişim tarihi: 19.03.2018); “...Ölüme bağll 
Hukukunda ima teorisi özelikle Alman Federal Mahkemesi'nin uygulaması doğrultusunda bir şekil kuralı olarak varlığını sürdürmekte iken; Türk-İsviçre Hukukunda ima teorisi daha ziyade yoruma sinır getiren bir kural olarak anlaşılmaktadır ${ }^{82}$. Yoruma sinır getirilmesinin gerekçesi ise vasiyetnamelerin tabi olduğu şekil kuralları ile açıklanmaktadır. Bununla birlikte ima teorisi, özellikle İsviçre öğretisinde, şekil sorunu ile yorum sorununu birbirine karıştırdığ 1 için de eleştiriye uğramakta ve bu iki sorunun birbirinden ayrı ele alınması gerektiği ifade edilmektedir ${ }^{83}$. Bu doğrultuda ilk aşamada, mirasbırakanın irade beyanının, onun bu beyanının nasıl anlaşılmasını istediği bulunacak şekilde yorumlanması gerektiği ve bu noktada vasiyetname metni dışında yer alan durum ve koşulların da dikkate alınacağ 1 belirtilmektedir. İkinci aşamada ise, yorum yoluyla anlamına ulaşılan irade beyanının, bu kez ilgili şekil kurallarına uygun olup olmadığının belirlenmesinin gerekeceği ifade edilmektedir ${ }^{84}$.

\section{C- GÖRÜŞÜMÜZ}

Kanaatimizce vasiyetnamelerin yorumunda her ne kadar açıklık teorisi vasiyetname metninden uzaklaşmamayı, metinden bağımsız yorum faaliyetinde bulunmamayı öngörmekte ise de, vasiyetname dışı olguların da hesaba katıldığı ima teorisi en uygulanabilir yorum kuralı olarak görünmektedir. Vasiyetnamede dayanak bulan birtakım olgular vasiyetname dışı olsa da dikkate alınmayı icap eder. Bu açıdan bakıldığında ima teorisi yorum kurallarına sinır getiren bir teori olarak görünmemektedir. Zira yorum yoluyla anlamına ulaşılan irade beyanının salt olduğu gibi kabul edilmesi yerine bu kez de ilgili şekil kurallarına uygunluk tesis edip etmediği araştırılarak iki aşamalı bir denetimden geçirilmektedir. Buna göre, vasiyetçinin dayanağ1 vasiyetname olan imalarının gerçekte ne anlama geldiğinin araştırılması yine vasiyetname içi olgularla mümkün olmaktadır.

tasarrufun (vasiyetnamenin) yorumlanmasinda uygulanacak genel kurallar, öncelikle vasiyetnamenin metnine bağll kalınarak sonuca gidilecektir. Bu yapılırken murisin iradesi ve (... ve dış etmenlere bağlllık da söz konusu olacaktır... ”3.HD, E.2013/9138; K.2013/11282; T.01.07.2013 https://emsal.yargitay.gov.tr (erişim tarihi: 19.03.2018); 3. HD, E.2014/22183; K. 2015/17797, T. 12.11.2015 www.kazanci.com.tr (erişim tarihi: 11.12.2017).

82 ÖNCÜ; s. 317-323'den naklen.

83 RASELLI, s. 1265, BREITSCHMID, s. 280.

84 WIEGAND, Art. 18 OR, Rn.54; İma teorisinin TBK madde 19/f.1 (Art. 18 Abs.1 OR) de yer alan düzenlemeye de aykırılık oluşturacağı yönünde, RASELLİ, s. 1266. 


\section{MIRAS SÖZLEŞMESININ YORUMU}

Yukarıda vasiyetnamelerin yorumunun irade prensibine göre yapılacağı, bunun da sebebinin vasiyetnamelerin tek taraflı irade beyanı ile oluşan bir hukuki işlem olduğu, yani iradenin bir muhatabının olmadığı şeklinde açıklanmıştı. Oysa miras sözleşmeleri iki taraflı hukuki işlemlerdir. Dolayısıyla da iradenin yöneldiği bir kişi vardır. Böyle olunca da, artık miras sözleşmelerinde yorumun irade prensibine göre değil de, TMK.m.2'den kaynaklanan güven prensibine göre yapılması gerekir. Buna göre, yorum yapılırken tarafların iradesinin ne olduğu değil de, karşı tarafin içinde bulunulan hal ve şartlara göre yapılan beyana ne anlam vermesi gerektiği araştırllır. Bu bakımdan, vasiyetnamenin yorumlanmasına ilişkin kurallar, ancak güvene göre yorumu ihlal etmedikleri ölçüde miras sözleşmesinin yorumlanmasında da uygulanırlar ${ }^{85}$.

Belirtmek gerekir ki, miras sözleşmesinin, bağlayıcı olmayan, yani vasiyetname niteliğinde bulunan hükümlerine güven prensibi uygulanmaz. Onlar, tek taraflı oldukları için, yine irade prensibine göre yorumlanırlar ${ }^{86}$. Oysa miras sözleşmesinde mirasbırakanın ne istediğini anlamak, onun gerçek maksadını araştırmak ve bulmak gerekecektir. Bu sebeple yorumda güven teorisi hakimdir ve yapılacak yorum objektif niteliktedir ${ }^{87}$. Objektif yorum ise, sözleşme taraflarının davranış ve açıklamalarının güven ilkesine göre yorumlanması anlamına gelmektedir. Burada güven ilkesine göre, ilgili muhatabın TMK md.2/I 1şığında bütün şartları göz önünde bulundurarak ne anladığı veya anlaması gerektiği araştırılır. Bir diğer anlatımla, sözleşme taraflarının dürüstlük ilkesine göre, somut olayın bütün hal ve şartları dikkate alınarak, dürüst ve makul sözleşme tarafı olarak o sözleşme kapsamında neyi istemiş sayılabilecekleri araştırılır ve bir sonuca ulaşmaya çalış1ırı ${ }^{88}$. İrade açıklamasının yorumunda sadece açıklamada yer alan hususlar değil, bununla birlikte diğer açıklama veya olaylar gibi dış unsurların da dikkate alınması gerekmektedir. Çünkü irade açıklamasının doğru ya da yanlış olup olmadığı ancak bu şekilde değerlendirilebilir. Sözleşmenin yorumunda kullanılan yorum araçları münferit irade beyanlarının yorumunda kullanılan yorum araçları ile aynıdır. Bu anlamda bir irade açıklamasının (burada sözleşmenin) yorumu sadece açıklama dikkate alınarak veya sadece açıklamada kullanılan

\footnotetext{
85 KOCAYUFUPAŞAOĞLU, § 27 III; OĞUZMAN, s. 171.

86 KOCAYUFUPAŞAOĞLU, § 27 III; SEROZAN, s. 151.

87 FAHRLAENDER, s. 34. BGE 64 II 187, 69 II 382, 75 II 284.

88 ÖZDOĞAN DALCI, s. 38.
} 
dil veya sistematik dikkate alınarak yapılmamalıdır. Bu bağlamda tarafların açık veya örtülü diğer açıklamaları da yorumun konusunu teşkil eder. Miras sözleşmesi de ölüme bağlı tasarruf olduğundan yorumda bulunurken ölüme bağlı tasarrufu iptal etmekten çok, bunu korumak, mirasbırakanın iradesine ve isteğine daha uygun düsser; bu sebeple, yorumda bu gayenin göz önünde tutulması, şüpheli ve müphem hallerde tasarrufun korunması lehine olarak yorum yapilması gerekir ${ }^{89}$. Favor testamenti olarak da isimlendirilen bu kural miras sözleşmelerinin yorumunda da esas alınır. Buna karşılık, bu prensip mirasbırakanın açıkça beyan ettiği bir hususu değiştirmeye, düzeltmeye veya tamamlamaya (miras sözleşmesindeki bir boşluğu doldurmaya) hizmet edeme $z^{90}$. Miras sözleşmesinin yorumunda dikkate alınacak olan güven teorisi uyarınca sözleşmedeki boşluğun mirasbırakanın farazi iradesi dikkate alınarak doldurulması mümkün olabilecektir. Öğretide, sözleşme yorumunda tarafların gerçek iradesi tespit edilemezse, sözleşme taraflarının davranış ve açıklamalarının güven ilkesine göre yorumlanacağı kabul edilmektedir ${ }^{91}$. Objektif yorum, sözleşmelerin normatif uygunluğu ile yani fiili uyuşma olmadığ 1 , sözleşmenin, tarafların farazi iradesine göre kurulmuş olduğu durum ile örtüşmektedir. Bu teoriye göre, "taraflardan her birinin beyanı (davranışı), diğer tarafin dürüstlük kuralı içinde bildiği veya bilmesi gereken şart ve durumlar da göz önünde tutarak anlamaya mezun ve mecbur olduğu şekilde yorumlanır. Bu yorum sonunda beyanların anlamı birbirine uyduğu takdirde, tarafların irade beyanları arasında hukukî uygunluğun mevcut olduğu hükmüne varılır" "92. Buna göre hâkim, kendisini mirasbırakanın yerine koyacak ve mirasbırakanın, makul ve dürüst bir mirasbırakanın yapacağ 1 gibi, irade beyanının meydana geldiği yer ve zamanda bildiği veya bilmesi gereken bütün şartları da dikkate alarak, söz konusu irade beyanını dürüstlük kurallarına göre yorumlayarak karar verecektir ${ }^{93}$.

Son olarak, miras sözleşmesinin yorumunda, sözleşmenin yapıldığg 1 zamanın koşulları dikkate alınmalı ve daha sonra oluşan statü ve koşullar tarafların amaçlarına uymuyorsa bunlar yorumda dikkate alınmamalıdır ${ }^{94}$.

\footnotetext{
89 FAHRLAENDER, s. 45, BAYGIN, s. 573 vd.

90 BGE 101 II 31; 98 II 73.

91 FAHRLAENDER, s. 46. DRUEY, §12, Rn.12.

92 VON TUHR, A./PETER, H., s. 287

93 VON TUHR./PETER; s. 288.

94 DEMIR, s. 1171.
} 


\section{SONUÇ}

Vasiyetnamelerin yorumunda uygulanacak kural irade prensibidir. $\mathrm{Bu}$ çerçevede, yorum konusunda esas olan, vasiyetnamenin veya miras sözleşmesinin metni ve sözüdür. Vasiyetçinin son arzu ve emirleri ancak buradan anlaş1labilir. Vasiyetnameler, tek tarafl1, varmas1 gerekli olmayan irade beyanı ile yapılan ölüme bağlı tasarruflar oldukları için korunması gereken bir beyan muhatabı yoktur. Bu sebeple yorumla bulunmas1 gereken vasiyetçinin açık olmayan iradesinin ne anlama geldiğidir, yoksa muhatap olmadığ1 için onun açısından beyanın ne anlama geldiği araştırılmaz. Mirasbırakanın beyanı, bu beyana dürüstlük kuralı (TMK m.2) çerçevesinde karşı tarafın vermesi gereken anlam değil, doğrudan doğruya söz konusu beyanın arkasında yer alan ve bu beyanla ifade edilmek istenen gerçek irade araştırılarak yorumlanır. Vasiyetnamenin metni yoruma yeterli olmazsa, bunun yanında yardımcı olarak, dış etki ve olaylara, mesela mirasbırakanın yazılı notlarına, mektuplarına, hısımlık ve dostluk ilişkilerine de bakmak gerekebilir. Vasiyetname dişındaki delillerin, gerek bulunduğu taktirde göz önüne alınmasını İsviçre doktrini ve içtihatları da kabul etmiştir. Hemen ifade edelim ki, vasiyetname dişındaki olgular ancak vasiyetnamenin yorumuna yararlar; fakat vasiyetnamede yaz1l olmayan bir hususun vasiyetnameye eklenmesine hizmet edemezler.

Hem Alman hem de İsviçre Hukukunda, ölüme bağlı tasarrufların yorumunda, açılık teorisinin geçerli olmaması gerektiği öğretide genel olarak kabul görmektedir. Nitekim çok açık gözüken ifadelerin bile aslında yorumlanmaya ihtiyacı vardır ve bir ifadenin açık nitelikte olup olmadığını tespit etmek de bir tür yorum faaliyetidir. Türk Hukukunda da ima teorisi ise genel olarak, mirasbırakanın iradesinin ancak vasiyetname metninde şekil koşullarına uygun olarak ima edilmişse, bu ima (dayanak, bağlantı noktası) dikkate alınarak iradeyi açıklamaya yönelik yorum yapılabileceği şeklinde tanımlanmaktadır

Miras sözleşmeleri iki taraflı hukuki işlemlerdir. Dolayısıyla da iradenin yöneldiği bir kişi vardır. Böyle olunca da, artık miras sözleşmelerinde yorumun irade prensibine göre değil de, TMK.m.2'den kaynaklanan güven prensibine göre yapılması gerekir. Buna göre, yorum yapılırken tarafların iradesinin ne olduğu değil de, karşı tarafin içinde bulunulan hal ve şartlara göre yapılan beyana ne anlam vermesi gerektiği araştırllır. Bu bakımdan, vasiyetnamenin yorumlanmasına ilişkin kurallar, ancak güvene göre yorumu ihlal etmedikleri ölçüde miras sözleşmesinin yorumlanmasında da uygulanırlar. 


\section{KAYNAKÇA}

AKSOY DURSUN, Sanem: "Ölüme Bağlı Tasarrufların Yorumuna Dair Bazı Düşünceler”, IÜHHFM , C.LXVI, S.2, 2008, s.311-326.

ANTALYA,Gökhan/SAĞLAM; İpek: Miras Hukuku, İstanbul, Legal Kitabevi, 2015.

BAYGIN, Cem: “Ölüme Bağlı Tasarruflarda Yorum”, AÜEHFD, C.IV, S.1-2 (2000), s.567-594.

BREITSCHMID, Peter: "Testament und Erbvertrag - Formprobleme", Peter Bereitschmid: Gesammelte Schriften aus Anlass seines 60. Geburtstages In praeteritum non vivitur, 2014, s.278-294.

DEMİ, Şamil: "Ölüme Bağlı Tasarrufların Yorumu”, TAAD, Y.4, S.14 (Temmuz 2013), s.1151-1173.

DRUEY, Jean N: Grundriss des Erbrechts, 3.Auflage,, Stämpfli Verlag, Bern, 1992.

DURAL, Mustafa/ÖZ, Turgut: Miras Hukuku, Filiz Kitabevi, İstanbul, 2019.

EREN/YÜCER AKTÜRK; Türk Miras Hukuku, Yetkin Yayınevi, Ankara, 2019.

ERGÜNE, Mehmet Serkan: Vasiyetnamenin Yorumu, On İki Levha Yayınc1lı, İstanbul, 2011.

ESCHER, Arnold: Kommentar zum schweizerischen Zivilgesetzbuch, Band III, das Erbrecht Dritte Auflage, Stämpfli Verlag, Zürich, 1960.

FAHRLÄNDER, Karl: Die außenstehende Tatsache in der Bundesgerichtlichen Praxis zur Testamentauslegung, Diss., Bern, 1948.

FANKHAUSER, Roland: "Bundesgericht, II. Zivilabteilung, 14.7./1.9.2005, Etat Du Valais Et Commune De Nendaz C. Eglise Nationale Protestante De Genève, Zivilrechtliche Berufung (5C.29/2005, BGE 131 III 601)", AJP 2006, s.749-754.

GLAUS, Hannes, Irrtumsanfechtung und Auslegung beim Testament, Zurich 1982.

HATEMİ, Hüseyin: Miras Hukuku, Vedat Kitapçı1ık, İstanbul, 2014. 
HRUBESCH-MILLAUER, Stephanie: Erbrecht, Dike Verlag, Zurich/ St. Gallen, 2011.

HRUBESCH-MILLAUER, Stephanie/BOSSHARDT; Martina: "Übersicht über die Rechtsprechung des Bundesgerichts im Jahr 2014 im Bereich Erbrecht", AJP 2015, s.506-509.

İMRE, Zahit/ERMAN, Hasan: Miras Hukuku, Der Yayınları, İstanbul, 2017.

İNAN, Ali Naim/ERTAŞ, Şeref/ALBAŞ, Hakan: Miras Hukuku, Seçkin Yayınc1lık, İzmir, 2012.

KAHRAMAN, Zafer: “Önceki Vasiyetnamenin Geri Alınması Beyanı İçeren İkinci Vasiyetnamenin Sonradan Üçüncü Bir Vasiyetname İle Geri Alınması", İnönü Üniversitesi Hukuk Fakültesi Dergisi Özel Say1 Cilt:2 Y11 2015, s.945-964.

KILIÇOĞLU, Ahmet M: Miras Hukuku, Turhan Kitabevi, Ankara, 2018.

KOCAYUSUFPAŞAOĞLU, Necip: Miras Hukuku, Üçüncü Bası, Filiz Kitabevi, İstanbul, 1987.

KÖSSINGER, Winfried: Handbuch der Testamentsgestaltung, Begründet von: Heinrich Nieder, Bearbeitet von: Reinhard Kössinger/Winfried Kössinger, 5. Auflage, 2015.

LEIPOLD, Dieter: Münchener Kommentar zum Bürgerlichen Gesetzbuch, Band 10 Erbrecht $\S 1922-2385, \S \S 27-35$ BeurkG, 7. Auflage, 2017.

LITZENBURGER, Wolfgang: Beck'sche Online Kommentar, Herausgegeben von Heinz Georg Bamberger/ Herbert Roth/Wofgang Hau/Roman Poseck, 44. Edition, Stand:01.11.2017, München 2017.

LORITZ, Karl G: Soergel BGB Kommentar zum Bürgerlichen Gesetzbuch, Erbrecht 2, §§ 2064-2273, §§ 1-35 BeurkG, Stand:Winter 2002/2003.

LÖHNING, Martin: Erbrecht, 2. Auflage, Vahlen Verlag, 2010.

LÜBTOW, Ulrich: Erbrecht, 1.Halbband, Duncker \& Humblot Verlag, Berlin, 1971

MANSEL, Heinz Peter: Bürgerliches Gesetzbuch Kommentar, Herausgeber:Othmar Jauerning, 16. Auflage, C.H.Beck Verlag, München, 2015. 
OĞUZMAN, Kemal: Miras Hukuku, gözden geçirilmiş 6. baskı, Filiz Kitabevi, İstanbul, 1995.

OLZEN, Dirk: Erbrecht, 2. neu bearbeitete Auflage, Gruyter Verlag, Berlin, 2005.

ÖNCÜ, Özge: "Vasiyetnamelerin Yorumunda İma Teorisi", Dokuz Eylül Üniversitesi Hukuk Fakültesi Dergisi, Cilt: 20, Say1: 2, 2018, s.307374.

ÖZDOĞAN DALCI, Nurcihan: "Sözleşmenin Yorumunda Gerçek İradenin Tespiti”, İnÜHFD Cilt:8 Sayı:1 Y11 2017, s.33-52.

ÖZTAN, Bilge: Miras Hukuku (Tablolar ve Örneklerle), Turhan Kitabevi, Ankara, 2017.

PICENONI, Vito: Die Auslegung von Testament und Erbvertrag, Diss., Zürich, 1955.

PIOTET, Paul: Schweizerische Privatrecht, Band IV/1, Erbrecht erter Halbband, Basel und Stuttgart, Helbing Lichtenhahn Verlag 1978 (PIOTET, 1978).

PIOTET, Paul: Traité de Droit Privé Suisse, Tome IV, Droit Successoral, 2ième édition, Editions Universitaires Fribourg, Fribourg 1988 (PIOTET, 1988).

RASELLI, Niccolo: "Erklärter oder wirklicher Wille des Erblassers?", AJP 1999, s. 1262-1266.

SCHERER, Inge: "Die Auslegung von Willenserklärungen „klaren und eindeutigen Wortlauts -BGH- Urt.v. 8.12.1982- IV a ZR94/81", Jura 1988, Heft:6, s. 296-310.

SEILER, Benedikt: Die Erbrechtliche Ungültigkeit: unter besonderer Berücksichtigung der Wirkungen in personeller Hinsicht, Schulthess Verlag, Zürich, 2017.

SEROZAN, Rona/ENGIN, Baki İlkay: Miras Hukuku, Seçkin Yayıncılık, İstanbul, 2018.

SEROZAN, Rona: "Ölüme Bağlı Tasarrufların Yorumuna Değişik Bir Yaklaşım”, Halit Kemal Elbir'e Armağan, İstanbul, 1996, s.425-437. 
STEINAUER, Paul Henri: Le droit des successions, Stämpfli Editions, Berne 2006.

ŞENER, Esat: Vasiyet Hukuku, Seçkin Yayıncılık, Ankara 1995.

WEIDLICH, Dietmar: Palandt. Bürgerliches Gesetzbuch, 70., neubearbeitete Auflage, C.H.Beck Verlag, München, 2011.

WIEGAND, Wolfgang: Basler Kommentar Obligationenrecht I Art.1529 OR, 5. Auflage, Herausgeber: Heinrich Honsell/Nedim Peter Vogt/ Wolfganf Wiegand, Basel, 2011.

VON TUHR, Andreas/PETER, Hans: Allgemeiner Teil des Schweizerischen Obligationenrechts, Band I, 3. Auflage, Zürich 1979/1984. 
